\title{
COVID-19 and the need of targeted inverse quarantine
}

\author{
Fabian Standl ${ }^{1} \cdot$ Karl-Heinz Jöckel $^{1} \cdot$ Andreas Stang $^{1,2}$ (D) \\ Received: 23 March 2020 / Accepted: 7 April 2020 / Published online: 24 April 2020 \\ (c) Springer Nature B.V. 2020
}

SARS-CoV-2 is circulating the world and causing people to suffer from COVID-19. Many countries answer with lockdowns and quarantine $[1,2]$ and in these countries, public life has come to a halt. For example, all childcare centers, Kindergarten, schools, universities, restaurants, sport and fitness clubs, shops that are not relevant to the universal service, and other facilities are currently closed in Germany and elsewhere. People are encouraged to work at home if possible.

\section{The dilemma of unfocused preventive measures}

The recommendation of social isolation of the whole population as currently practiced in Germany is driven by the idea that the spread of the disease is reduced which may prevent a sudden overcrowding of hospitals with seriously ill COVID19 cases as has been observed in Northern Italy. Sebastiani et al. [3] in this issue show that the strict isolation measures as taken in Lombardy and later on in all over Italy was associated with the reduction of progression of the epidemic. This approach has enormous negative economic and societal consequences [4] but may be justified in the beginning of an epidemic when infection rates, hospitalization rates and case-fatality cannot be stratified by potential determinants. As soon as more detailed data on the spread and case-fatality of the corona infections is available, a targeted, that is, riskadapted approach to prevent corona infections is possible and should be implemented because social isolation of the entire population will lead to unsustainable conditions in the population in the long run. For a targeted strategy to prevent

Andreas Stang

imibe.dir@uk-essen.de

1 Institute of Medical Informatics, Biometry and Epidemiology, University Hospital Essen, Essen, Germany

2 School of Public Health, Department of Epidemiology, Boston University, Boston, USA deaths from COVID-19, a high-risk approach is possible and does not have the enormous negative economic and societal consequences.

\section{Which subpopulations are high-risk populations for COVID-19 death?}

Available data from the pandemic indicate that COVID-19 deaths occur predominantly among the elderly and comorbid people. For example, in Italy the case fatality $(\mathrm{CF})$ as of March 17, 2020 was $0.3-0.4 \%$ among people aged $30-49$ years, $1.0 \%$ among people aged $50-59$ years, $3.5 \%$ among people aged $60-69$ years, $12.8 \%$ among people aged $70-79$ years, and $20.2 \%$ among people aged 80 years or more [5]. The COVID-19 outbreak at the cruise ship Diamond Princess showed that the virus infected 621 out of 3711 persons within 4 weeks and six died. All of the deceased were at least 70 years old and at least two of them had comorbidities [6]. Furthermore, data from China show that people with comorbidities have higher CF (cardiovascular diseases: $11 \%$, diabetes: $7 \%$, chronic respiratory diseases: $6 \%$, hypertension: 6\%, cancer: 6\%) whereas the overall $\mathrm{CF}$ in China as based on an analysis of 72,314 patient records was $2 \%$ [7]. Recent data on the case-fatality in Italy [8], Spain [9], and the U.S. [10] show similar age gradients of the case-fatality with barely any case-fatality below age 60 years and a cubic increase of the case-fatality among the elderly (Fig. 1).

\section{How should we do targeted prevention?}

We introduce the term 'inverse quarantine' (IQ) as a Public Health approach to save lives and to keep the economy vital. We understand IQ as a measure that prevents fatal outcomes during infectious epidemics or pandemics by isolating people with high risk but not yet infected. This approach is in contrast to usual quarantine where infected people are isolated. High risk people could isolate themselves e.g. at home until a pandemic subsides enough that isolation is not 


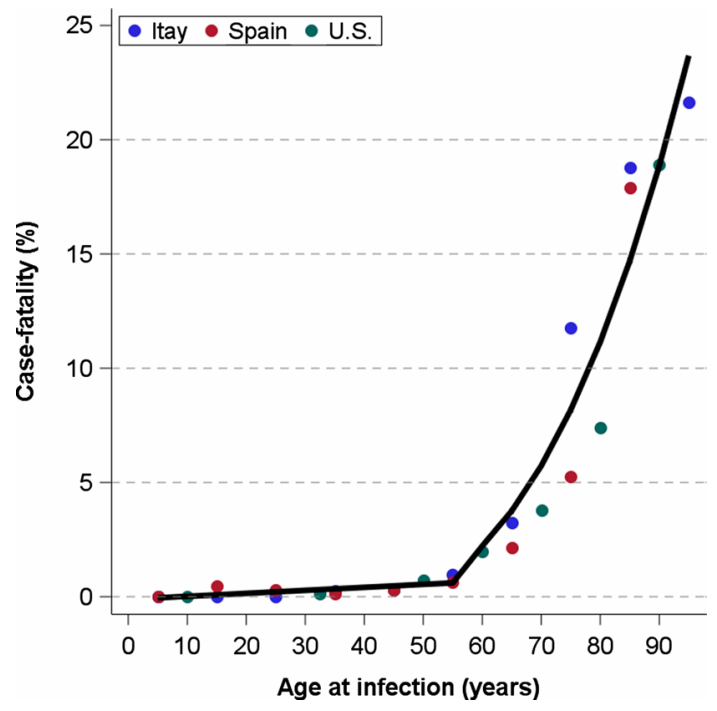

Fig. 1 Association between age at diagnosis of COVID-19 and casefatality in Italy (up to March 16, 2020), Spain (up to March 22, 2020), and the U.S. (up to March 16, 2020)

needed anymore. Following this logic, it is necessary to ration medical means e.g. for disinfection and selling them preferably to people of high risk of death if they would get infected. For COVID-19 this means that comorbid people and the elderly should isolate themselves and should preferably get disinfection etc. With this targeted approach, the vast majority of COVID-19 deaths can be prevented.

\section{What does that mean for the population of lower risk not isolating itself?}

Within the low-risk population not isolating itself, COVID19 can spread and will produce illness. However, COVID-19 among low risk populations (i.e. younger people, healthy people) exceptionally produces deaths and helps to reach herd immunity in less time than isolating the whole population. Furthermore, the reduction of the time to reach herd immunity reduces the risk that pathogen strains becomes more aggressive (selection effects).

In conclusion, epidemiological data can help to plan a targeted COVID-19 prevention strategy for high risk people by age and comorbidities. People above the age of 80 are at very high-risk as well as persons with underlying comorbidities such as cardiovascular diseases, diabetes, hypertension, chronic respiratory disease and cancer. IQ will not only save lives but keep the economy vital and reduce the time until herd immunity is reached which in the end further protects high-risk groups against COVID-19.

Acknowledgements Dr. Stang receives a grant from the German Federal Ministry of Education and Science (BMBF), Grant Number 01ER1305.

\section{References}

1. World Health Organization. Coronavirus disease 2019 (COVID19). Situation report-45. 2020. https://www.who.int/docs/defau lt-source/coronaviruse/situation-reports/20200305-sitrep-45-covid -19.pdf?sfvrsn=ed2ba78b_2. Accessed 6 April 2020.

2. World Health Organization. Coronavirus disease 2019 (COVID19). Situation report-58. 2020. https://www.who.int/docs/defau lt-source/coronaviruse/situation-reports/20200318-sitrep-58-covid -19.pdf?sfvrsn=20876712_2. Accessed 6 April 2020.

3. Sebastiani G, Massa M, Riboli E. Covid-19 epidemic in Lombardy: implications for public health measures. Eur J Epidemiol. 2020. https://doi.org/10.1007/s10654-020-00631-6.

4. Lynch DJ, Long H. With unprecedented force and speed, a global recession is likely taking hold. The Washington Post. Washington. 2020. https://www.washingtonpost.com/business/2020/03/14/ recession-economy-coronavirus-jobs/. Accessed 6 April 2020.

5. Onder G, Rezza G, Brusaferro S. Case-fatality rate and characteristics of patients dying in relation to COVID-19 in Italy. JAMA. 2020;2020:E1-2.

6. McFall-Johnson M. How the 'failed' quarantine of the Diamond Princess Cruise ship started with 10 coronavirus cases and ended with more than 700. Business Insider. 2020. https://www.busin essinsider.de/international/how-diamond-princess-cruise-shipcoronavirus-quarantine-went-wrong-2020-2/?r=US\&IR $=\mathrm{T}$. Accessed 6 April 2020.

7. Zhang Y. Vital surveillances: the epidemiological characteristics of an outbreak of 2019 novel coronavirus diseases (COVID19)—China. 2020. http://weekly.chinacdc.cn/en/article/id/e5394 6e2-c6c4-41e9-9a9b-fea8db1a8f51. Accessed 6 April 2020.

8. Sanità Istituto Superiore di Sanità. Epidemia COVID-19. Aggiornamento nazionale. 16 marzo 2020 - ore 16:00. Rome: Istituto Superiore di Sanità; 2020. p. 1-9. https://www.epicentro.iss.it/ coronavirus/bollettino/Bollettino\%20sorveglianza\%20integrat a\%20COVID-19_16\%20marzo\%202020.pdf. Accessed 6 April 2020.

9. Centro de Coordinación de Alertas y Emergencias Sanitarias. Actualización $n^{\circ}$ 52. Enfermedad por el coronavirus (COVID-19). 22.03.2020 (datos consolidados a las 21:00 horas del 21.03.2020). Madrid: Centro de Coordinación de Alertas y Emergencias Sanitarias; 2020. https://www.mscbs.gob.es/profesionales/saludPubli $\mathrm{ca} /$ ccayes/alertasActual/nCov-China/documentos/Actualizac ion_52_COVID-19.pdf. Accessed 6 April 2020.

10. CDC COVID-19 Response Team. Severe outcomes among patients with coronavirus disease 2019 (COVID-19) - United States, February 12-March 16, 2020. MMWR. 2020;69:343-6.

Publisher's Note Springer Nature remains neutral with regard to jurisdictional claims in published maps and institutional affiliations. 